University of Wollongong

Research Online

Faculty of Business - Papers (Archive)

Faculty of Business and Law

$1-1-2019$

Mixed views in the academy: academic and student perspectives about the utility of developing work-ready skills through WIL

Lisa McManus

University of Tasmania, lisa.mcmanus@utas.edu.au

Laura L. Rook

University of Wollongong, Irook@uow.edu.au

Follow this and additional works at: https://ro.uow.edu.au/buspapers

Part of the Business Commons

Research Online is the open access institutional repository for the University of Wollongong. For further information contact the UOW Library: research-pubs@uow.edu.au 


\title{
Mixed views in the academy: academic and student perspectives about the utility of developing work-ready skills through WIL
}

\author{
Abstract \\ Work-integrated Learning (WIL) can be a vehicle for the development of students' work-ready skills. This \\ paper presents the views of undergraduate business students and academics about the role and \\ perceived importance of work-ready skills in the business curriculum and the perceived role of WIL \\ activities in enabling the development of work-ready skills. A total of 50 business students and 24 \\ academics from a number of faculties across the university participated. While students and academics \\ both agree that a combination of on and off campus WIL activities are most effective for developing \\ work-ready skills, students and academics hold different views to the importance of work-ready skills in \\ the curriculum and the importance of including specific skills such as project planning. These findings \\ have implications for the development of work-ready skills and embedding both WIL and non-WIL \\ activities in undergraduate courses for business school educators and university policy makers. \\ Disciplines \\ Business

\section{Publication Details} \\ McManus, L. \& Rook, L. (2019). Mixed views in the academy: academic and student perspectives about \\ the utility of developing work-ready skills through WIL. Studies in Higher Education, Online First 1-15.
}

This journal article is available at Research Online: https://ro.uow.edu.au/buspapers/1584 
Mixed views in the academy: academic and student perspectives about the utility of developing work-ready skills through WIL

Professor Lisa McManus, University of Tasmania

Dr Laura Rook, University of Wollongong

\begin{abstract}
Work-integrated Learning (WIL) can be a vehicle for the development of students' work-ready skills. This paper presents the views of undergraduate business students and academics about the role and perceived importance of work-ready skills in the business curriculum and the perceived role of WIL activities in enabling the development of work-ready skills. A total of 50 business students and 24 academics from a number of faculties across the university participated. While students and academics both agree that a combination of on and off campus WIL activities are most effective for developing work-ready skills, students and academics hold different views to the importance of work-ready skills in the curriculum and the importance of including specific skills such as project planning. These findings have implications for the development of work-ready skills and embedding both WIL and non-WIL activities in undergraduate courses for business school educators and university policy makers.
\end{abstract}

Keywords: work-ready skills, work-integrated learning, business education, graduate skills, work-based learning 


\section{Introduction}

Australian universities are increasingly investing in WIL as a way of promoting graduate employability among other outcomes including work-ready skill development (Rowe and Zegward 2017; Rowe et al. 2018). The recent expansion of WIL programs in Australia has been driven by the Federal Government’s agenda “...to address skills shortages and provide all students with work-related experiences to increase work readiness” (Orrell 2011, 5). Motivated by a need to fill skill shortages and satisfy recruitment needs, employers are linking work-ready skill development with participation in WIL placement programs (McKinnon 2011; Patrick et al. 2008).

Despite the focus on developing work-ready skills, industry opinion has deemed Australian business graduates as not being 'job ready' and 'deficient in vital elements of the managerial skill set' including leadership, critical thinking, self-reflection, conflict management and decision-making skills (Jackson and Chapman 2012). The lack of work-ready skills management graduates are developing incurs significant economic and social costs (Chevan and Carter 2018). As such it has been suggested that more could be done in the university curriculum to develop students' wider skills through embedding employability skills such as team work, communication, leadership, critical thinking and problem solving into the curriculum (Abbasi, Ali and Bibi 2018; Abraham and Karns 2009; Archer and Davidson 2008; Chevan and Carter 2018; Cumming 2010; Freudenberg, Brimble and Cameron 2011; Jackling and De Lange 2009; Jackson 2009, 2013a, 2013b; Jackson and Chapman 2012; Kavanagh and Drennan 2008; Lowden et al. 2011; ACNeilsen Research Services 2000). Research has also found a significant gap in the expectations of stakeholders (Patrick et al. 2008; QS 2018) which has led to negative impacts on the design of WIL programs and the uptake of work-ready skills by graduates (Patrick et al. 2008; Jackson 2013a:Rook 2015). 
The primary aim of the study is to unearth students' and academics' views in relation to work-ready skills to be incorporated in the proposed development of a WIL program in the undergraduate business curriculum of an Australian regional university. The following research question was established: What work-ready skills do students and academics view as important for developing through a WIL program? Data to answer this question was obtained using an online survey of business students and academics. The paper is structured to review relevant literature on the link between work-ready skills and WIL, followed by an outline of the methodology and presentation of the findings. The final section of the paper provides a discussion of the implications of the findings and suggestions for future research.

\section{Literature review}

\section{Stakeholder theory}

The role of higher education institutions is changing. There is an increased need for universities to engage more with external stakeholders and develop partnerships and trust with communities through strengthening their commitment to provide employable graduates (Leisyte et al. 2014; PwC 2016; Rook 2016). While there is no universally agreed upon definition of stakeholder theory or its application to education, it has been acknowledged that identifying stakeholders that influence or impact on partnerships can provide important strategic insights (Leven, Bok and Evans 2010). Freeman (1984) defines a stakeholder as any group or individual who is affected by or can affect the achievement of the organisation. Freeman's description also encourages organisations to be cognisant of all stakeholders and provides the foundation for stakeholder-based arguments that organisations should be managed with concern for all relevant stakeholders (Freeman 1984; Laplume, Sonpar and Litz 2008). There are a number of stakeholders who affect or are affected by WIL including universities, students, academics, government, industry, careers advisors, professional and community associations, each with 
their own motivations and agendas (Jackson, Rowbottom and Ferns 2017; Patrick et al. 2008; Pilgram 2012). When one considers WIL and the development of WIL programs from a stakeholder theory lens, the focus becomes one of recognising different stakeholder perspectives and needs when designing and implementing WIL programs in order to facilitate a collaborative approach to improve WIL experience and outcomes for students, employers and universities (Jackson, Rowbottom and Ferns 2017; Patrick et al. 2008).

Understanding perceptions of the importance of work-ready skills in the business discipline and the perceived role of WIL in enabling the development of work-ready skills is important for both students' and academics' 'buy in'. For students, 'buy in' is essential for effective learning as it gives students a clear understanding of the material they are learning (Gold et al. 2010; Biggs 2003; Gold et al. 2010; Jackson 2013b). Academic 'buy in’ is essential as academics are responsible for the design and implementation of WIL programs whether they include off or on campus activities. It is therefore also important that academics' views are considered when planning, designing and implementing WIL programs.

\section{The link between work-ready skills and WIL}

Work-integrated Learning (WIL) in the Australian higher education (HE) sector has been defined as an umbrella term for a range of approaches that integrate theory with the practice of work (Patrick et al. 2008; Universities Australia and the Australian Collaborative Education Network Strategy 2015). Rowe, Winchester-Seeto and Mackaway (2012) have categorised WIL programs as either off or on campus activities and provide a grading of WIL activities in terms of the level of community engagement. The activities categorised as predominantly offcampus include internships, community service and day site visits (Rowe, Winchester-Seeto and Mackaway 2012). The activities categorised as predominantly on campus activities include virtual projects, panel sessions and job readiness programs (Rowe, Winchester-Seeto and 
Mackaway 2012). With previous research finding that WIL is an important vehicle for enabling students to develop their professional repertoire of skills and knowledge, WIL is increasingly being considered by universities to satisfy industry and student needs by enabling the attainment of the skills to allow students to 'hit the ground running' when they enter the workforce (Sleep and Read 2006; ALTC 2009; Smith et al. 2009; Mcilveen 2008; Jackson 2016). For universities, WIL has the potential to provide students the payoff from their investment in education (Abeysekera 2006) by improving the transition from university to work through skills development (Jackson, Fleming and Rowe 2018), thereby becoming a strategy for universities looking to differentiate themselves in the competitive higher education market through the enhancement of graduate employability (Brimble and Freudenberg 2010; Ernst \&Young 2011; Jensen 2009; Rowe et al. 2018). This is particularly so for international students who are also looking to engage with WIL to gain local experience and transferrable skills to improve their prospects of gaining employment (Jackson 2016; Gribble 2014; Harrison and Felton 2013). Despite these purported positive benefits, research reports WIL as resource intensive having workload implications for academics and administrative staff who design, teach, administer and support WIL courses when compared to traditional classroom-based courses (Patrick et al. 2008; Clark et al. 2016).

Defining and measuring work-ready skills is difficult and unresolved. This may be attributed to the multiple terms used in the literature. For example, terms used instead of 'workready skills’ include but are not limited to: 'graduate capabilities’ (Oliver 2011), 'graduate skills’ (Australian Business Deans Council (ABDC), 2008), 'non-technical skills’ (Jackson and Chapman 2012) and 'generic attributes' (Barrie 2006). In Australia, work-ready skills are usually addressed through university graduate attributes which have come to be accepted as an orienting statement of education outcomes used to inform curriculum design and the provision of learning experiences at a university level (Barries, Hughes and Smith 2009 in Rook 2015; 
Oliver et al. 2007). In 2014, discipline specific learning threshold standards were released and endorsed by the Australian Business Deans Council which focussed on defining learning outcomes for graduates in the disciplines of accounting, marketing, economics, finance and tourism. These threshold standards have provided a valuable benchmark for designing degrees with appropriate learning outcomes as required under the Higher Education Standards Framework. There has been a shift in stakeholders' views of the best way to embed work-ready skills in the Australian higher education sector. Additionally, other research suggests students see value in developing work-ready skills (Jackson 2013b; Gill 2018; Rae 2007; Tymon 2013) other research findings suggest students do not (Moreau and Leatherwood 2006; Tomlinson 2008). As such, there has been a call for work-ready skills to be contextualised so that students find them meaningful and relevant to their studies (Jorre de St Jorre and Oliver 2017; Venkatraman et al. 2016).

Findings from previous research also suggest there is a link between students' participation in WIL activities and their capacity for developing work-ready skills. WIL programs can support students to develop their work-related skills and/or pre-professional identity and can have a positive impact on their workplace employability as well as clarifying a student's career intentions and increase engagement with course material (Rhodes and Shiel 2007; Sleap and Reed 2006; Collin and Tynjala 2003; Cooper, Orrell and Bowden 2010; Smith et al. 2009; Dressler and Keeling 2011; Jackson 2017; Zegward and Coll 2011; Silva et al. 2016). Work-related skills include the ability to think critically, to reflect, to form and build professional relationships, to communicate at a high-level and to recognise the contribution of degree-related knowledge and skills to future careers (Cooper, Orrell, and Bowden 2010; Tynjala, Valimaa, and Sarja 2003; Smith et al. 2009; Rhodes and Shiel 2007; Sleap and Reed 2006; Dressler and Keeling 2011; Weisz 2000). Research also suggests that WIL enables students to be competent and astute in applying knowledge to understand practical action, to 
be confident in themselves as learners, as community members, as well as be culturally aware and civic minded citizens (Cooper, Orrell, and Bowden 2010). This strong connection between WIL, work-ready skills and employability supports the notable increase in the development of WIL programs more broadly across all disciplines including business (Australian Learning and Teaching Council 2009; McLennan and Keating 2008).

\section{Research methods}

\section{Sample}

To explore the views of academics and students surrounding WIL and work-ready skills needed by students, an electronic survey questionnaire was administered using SurveyGizmo in the business school at a regional university ${ }^{1}$. The regional university is a small dual-sector university. The business school delivers both undergraduate and postgraduate programs in the accounting, economics, management and marketing disciplines, with both face-to-face and online modes. The surveys were designed to gather students' and academics' views and knowledge of the university's work-ready skills, type of WIL activities that they consider effective for developing student work-ready skills, as well as a range of other questions in relation to WIL. The surveys were pilot tested prior to their administration. The student survey was pilot tested by six business school undergraduate students and the academic survey was pilot tested by five academics. No issues of ambiguity or intelligibility of the survey questions were identified.

The initial samples consisted of students enrolled in the business school undergraduate programs across all years and included both part-time and full-time students (888) and a random sample of academics employed at the regional university from the business school as well as other faculties that had established WIL programs such as health and education (250). An email was sent to members of each stakeholder group detailing the study, describing 
relevant terms and providing an electronic link to the survey together with a letter describing the study's ethics approval. A second email was sent approximately three weeks following the initial contact and a third email was sent two weeks later. A total of 50 students and 24 academics from faculties across the university completed the survey. Academics from faculties where WIL programs have been established were included in the study to provide informed views based on their experience with the type of WIL activities that they consider effective for developing student work-ready skills. The response rate for each stakeholder group was therefore, students $5.6 \%$ and academics $9.6 \%$.

While these response rates are low, and the two samples are small (particularly the academic group with fewer than 30), it is important to consider sources of bias (such as nonresponse bias). Previous research has found that low response rates do not necessarily lead to biased results (e.g., Rindfuss et al. 2015). The response rates of this study are reflective of declining participation rates across all countries and in most disciplines (e.g., Atrostic et al. 2001; Brick and Williams 2013; Groves 2011 and Singer 2006). To investigate for potential response bias, responses by students to the first and second email contact were examined to test for differences across all survey questions. Kolmogorov Smirnov tests of differences revealed no differences in the distribution of responses between first and second student responses to all items except for the effectiveness of on-campus group projects with internal clients $(D=1.414 ; p<0.05)$. In comparison, no differences in the distributions of academic first and second responses across all items were identified using Kolmogorov Smirnov tests of differences. Additionally, due to the small sample size the study could be open to self-selection bias, where the findings of the study are not generalisable to the population. To examine for the existence of self-selection bias, sample estimates are compared to population parameters. As the population parameters are unknown, the demographic characteristics of the two samples were considered against the authors' knowledge of both the business school's undergraduate 
business students as well as academics from across the university. Based on the sample characteristics of both cohorts (including age, gender proportion, campus, education level and employment status) the demographics of both samples are considered to be consistent with both authors' knowledge of the school's undergraduate students as well as the academics across the university.

\section{Data Collection}

Both stakeholder groups were asked their opinion, on a five-point scale ranging from “1” = unimportant to " 5 " = very important (Tables $1,3,4,7)$, as well as a six-point scale ranging from " 1 " = strongly disagree to "” 6 " = strongly agree (Tables 2,5 ). To develop the survey questions, previous literature was reviewed, and the findings informed the development of the questions that were included in the surveys to both academics and students. For example, the previous literature was reviewed, and several WIL benefits were identified (presented in Table 6). Questions in relation to these benefits were then included in the surveys, and the two groups were asked to rate the importance of these benefits to identify the highest rated benefits that could accrue from the proposed WIL program. For a detailed list refer to appendix A.

Prior to the initial analysis, the data was screened for accuracy, missing data, multicollinearity, outliers, linearity, normality and homoscedacity following Hair, Anderson, Tatham and Black (2010). Problems were identified with missing data and non-normal distributions. Assessment of the two data sets identified seven students and three academic respondents with missing data. Inspection of the missing data suggested that it was missing 'randomly'. As no item had greater than 5\% of missing values and no significant correlations existed between the missing data, it was decided that the data was missing completely at random and therefore, the missing values were replaced with the mean value on each item, to not alter the underlying distribution (Hair et al. 2010). Shapiro-Wilks tests of normality (which work best with data sets of less than 50) were conducted in SPSS version 26, with all variables 
across the two groups identified as having non-normal distributions ( $p<0.05$ for all tests). As all variables are non-normally distributed, non-parametric tests were conducted throughout the study.

\section{Sample Characteristics}

Table 1, Panels (a) and (b) below, present the main demographic characteristics of the student and academic respondents. The average age of the student group is 30.5 years and 49.6 years for academics. The gender of the student group is similar with 24 male respondents and 26 female respondents. Most students are enrolled at the main campus $(62 \%) .87 .5 \%(n=21)$ of the academic respondents are employed in the higher education sector of the regional university, 13 (54.2\%) possess a master's level postgraduate degree and 11 academics (45.8\%) hold a Doctoral qualification. Most academics are employed full-time ( $\mathrm{n}=15$ or $62.5 \%$ ) with 33.3\% $(n=8)$ and 4.2\% $(n=1)$ being sessionally and part-time employed, respectively.

\section{Insert Table 1 Here}

\section{Findings}

Non-parametric Mann Whitney $U$ Tests of Independent Samples have been undertaken to test differences in the distributions of responses of the two stakeholder groups, as the sample size of the Academic group $(n=24)$ is lower than the threshold value of 30 to enable the use of parametric tests and each variable is non-normally distributed. To provide a more meaningful interpretation of the results, mean scores rather than median values have been reported herein. As the objective of the study was to examine any differences in responses between the two groups, it was considered more appropriate to apply tests of differences rather than multivariate analyses. Multi-variate analyses are deemed more appropriate when the purpose is to explain the relationship between variables, the explanatory power of a number of independent 
variables to a dependent variable or the structure of multiple variables, which were not the purposes of this study.

Table 2 below presents the mean responses for both academics and students to a range of questions in relation to work-ready skills. The student group rated all questions higher than the academic group except for work-ready skills are important to me, students acquire workready skills regardless of their discipline of study and networking with industry is an important aspect of a student's learning. There was a significance difference between the responses for the two stakeholder groups, with the academic group responding significantly higher than the student group to the question: work-ready skills are important to me $(U=944.0 ; p=0.000 ; r$ $=0.47)$. Students responded just over the slightly disagree response to work-ready skills are important to me $\left(\overline{\mathrm{x}}_{\mathrm{S}}=3.23\right)$, being the only question rated below the mid-point of the scale and therefore on the negative-side, compared to the academic group that responded slightly above the moderately agree response $\left(\overline{\mathrm{x}}_{\mathrm{A}}=5.08\right)$. Also, the student group responded with slightly agree to the statement: lecturers discuss work-ready skills and the importance of them $\left(\bar{x}_{\mathrm{S}}=\right.$ 4.06).

\section{Insert Table 2 Here}

Both the student and academic groups identified that a combination of on and offcampus activities were the most effective for developing student work-ready skills (student group $=62 \%$ and academic group $=79.2 \%$ ). A quarter of the student group thought that solely off-campus activities would be effective in developing student work-ready skills (student group $=24 \%$ ) whereas only $8.3 \%$ of the academic group rated this as being effective. There was no significant difference between the two groups responses.

\section{Insert Table 3 Here}


The two stakeholder groups were also asked to rate the importance of several workready skills and skills that should be acquired through studying a business undergraduate degree. Project planning was rated highest by the student cohort $\left(\bar{x}_{\mathrm{S}}=4.55\right)$ compared to the academic group that rated this as the least important graduate/skill $\left(\bar{x}_{\mathrm{A}}=3.85\right)$. The responses between the two groups for this attribute/skill were significantly different $(U=271.00 ; p=$ 0.000; $r=-0.458)$. Significant differences between other importance ratings were also found for: employability skills: $\bar{x}_{\mathrm{S}}=4.46$ and $\bar{x}_{\mathrm{A}}=4.80(U=768.00 ; p=0.035 ; r=0.245)$; selfmanagement: $\bar{x}_{\mathrm{S}}=4.41$ and $\bar{x}_{\mathrm{A}}=4.80(U=802.00 ; p=0.012 ; r=0.292)$; strategic management: $\bar{x}_{\mathrm{S}}=4.36$ and $\bar{x}_{\mathrm{A}}=3.91(U=362.00 ; p=0.004 ; r=-0.332)$. While the student group rated project planning as the most import skill, inter-generational tolerance was rated as the least important. In comparison, the academic group rated employability skills and selfmanagement as the most important skills and project planning as the least important.

\section{Insert Table 4 Here}

Table 5 below presents the responses to eleven statements in relation to WIL programs. While no differences tests were found to be statistically significant, on the six-point scale from 'strongly disagree' to 'strongly agree', the student group's responses were all above the midpoint of the scale $(\bar{x}=3.5)$ except for WIL programs are better suited to Vocational Education Programs to which students responded a little more than 'slightly disagree' $\left(\bar{x}_{\mathrm{S}}=\right.$ 3.36) which was similar to the academic group response $\left(\bar{x}_{\mathrm{A}}=3.29\right)$. The largest difference between the two groups responses was to the statement workplace ethics should be taught to students prior to commencement of a WIL program, with the student group responding as moderately agree $\left(\bar{x}_{\mathrm{S}}=4.96\right)$ compared to the academic group that responded closer to strongly $\operatorname{agree}\left(\bar{x}_{\mathrm{A}}=5.42\right)$.

\section{Insert Table 5 Here}


Six reported benefits of WIL programs were also assessed by students and academics and responses are presented in Table 6 below. Students rated increased employability, communication skills and professionalism as the top three benefits. In comparison, academics viewed professionalism, communication skills and discipline knowledge as the most important. Additionally, the academic group rated professionalism significantly more important than the student group $(U=437.5, p=0.046, r=0.23)$.

\section{Insert Table 6 Here}

The importance of seven types of assistance that could be provided to academics managing a WIL program was also included in the study. Only the academic group were asked to rate the importance of each type of assistance (see Table 7 below). The top three important types of assistance were networking with employers, specific guidelines and WIL teaching techniques. The least important type of assistance was considered by academics to be legal information.

\section{Insert Table 7 Here}

\section{Discussion and Conclusion}

This study has sought to examine the views of undergraduate business students and academics on the role and importance of the development of work-ready skills through WIL activities and investigate any differences between the two groups' expectations surrounding WIL's use for developing these skills. The findings of the study highlight a misalignment between the views of both groups.

One surprising finding was the students' view that work-ready skills were not overly important to them. This finding supports some previous research findings that students do not perceive value in developing work-ready skills in higher education such as Rae (2007) and 
Tymon (2013) but conflicts with other research findings that suggest that students do appreciate the value in developing these skills (Moreau and Leatherwood 2006; Tomlinson 2008). Previous research also suggests that if students do not perceive that the attainment of certain skills or attributes is important, they are less likely to focus on or spend their time and energy on their acquisition (Biggs 2003; Jackson 2013a). Learning theory suggests that student motivation and commitment to learn is an essential prerequisite of effective learning outcomes (Gold et al. 2010). If activities central to WIL programs are developed as vehicles for the learning of these skills and students do not consider these as important skills to learn, the validity of WIL programs must come into question. For effective learning students must be convinced of the importance and value of the skills and attributes that WIL programs are seeking to impart. This is particularly important in universities where WIL programs are not part of the core program but are chosen as an elective. Students may not elect to undertake WIL activities and miss an opportunity to develop the essential employability skills that they might need, and employers are calling for. Additionally, enriching the perceived value of these workready skills may have a positive impact on students' abilities to identify their own skill capabilities, and also enable students to describe them in a manner that improves their graduate employability. Conversely, as academics perceive work-ready skills as being important for students to attain, the assurance and inclusion of work-ready skills in their subjects and courses, particularly WIL programs, will have significance and will be a central part of the curriculum.

This difference in the views of students and academics to the importance of work-ready skills mirrors the identified skills gap between the employability skills employers require graduates to possess and the actual work-ready skills students have upon graduation, as well as a continuing limited alignment between the views of students and other stakeholder groups (Tymon, 2013). Universities, and academics involved and not involved, in WIL programs must more clearly articulate the importance of work-ready skills attainment to students and do so in 
such a way as to enhance students' understanding of these skills and the importance they place on gaining them while undertaking their degree, particularly in relation to WIL programs. By making skills development activities in WIL programs more overt students' engagement and ‘buy in’ should benefit and potentially provide increased work-ready skills attainment.

While some alignment was found between student and academic views on the combination of on and off-campus activities as being most effective for developing student work-ready skills, there was a significant disconnect between the views of the two groups in relation to the specific skills considered to be most, and least, important. This misalignment is best illustrated by consideration of project planning which was deemed to be the number one work-ready skill that students viewed as the most important for them to learn (from a list of 17 skills), yet academics viewed this skill as having the least importance. Another skill that was also viewed significantly higher by the student cohort was strategic management. Furthermore, students viewed employability skills and self-management significantly lower than academics who rated these two skills as the equal most important work-ready skills students attain during their undergraduate degree. These are interesting findings that provide further evidence of a misalignment between the viewpoints of academics and students. Further illustration of this misalignment of viewpoints, is provided by comparing these findings with some of the graduate skills that have been identified as lacking by employers.

While communication skills, team work, strategic thinking, problem solving, employability skills, self-management, adaptability and interpersonal skills have been noted in recent research as the most important skills required by employers (QS 2018; Abbasi, Ali and Bibi 2018; McMurray et al. 2016), and also viewed in the top ten skills by students and academics in this study, a number of skills have been identified previously by employers as being important but were considered to be relatively unimportant by both students and academics. The QS (2018) 
provides a global perspective through surveying 11,000 employers and 16,000 students and measures the importance of core skills against the satisfaction factor (a measure of how many employers are satisfied with the particular skill in their graduate hires). Students were found to be over valuing the importance of creativity and leadership skills and undervaluing flexibility/adaptability and teamwork, as according to employers the ability of students to learn is more important than their creativity (QS 2018). Students in this study rated creativity and leadership as one of the least important skills and teamwork as one of the most important skills, flexibility was viewed by students as relatively unimportant but as the fourth most important skill by academics. In addition, Kreber (2006) in a multiple country study, and Andrews and Higson (2009) based on a four country European study, noted that creativity was an important skill required by employers, while the two groups in this study rated this is one of the least important work-ready skill. While a comparison to international studies identifies a disconnect between "wish lists" of graduate skills by employers, these lists are also similar to Australian employer wishes (Cumming 2010). In the context of this misalignment between stakeholders' expectations of work-ready skill requirements and needs, questions must continue to be raised as to how to develop a WIL program that delivers on the development of graduate work-ready skills viewed as being important by all stakeholders? Should WIL programs endeavour to meet all stakeholder needs? Do the skills needs of one stakeholder group (e.g., employers) trump all other groups? Finding answers to these questions and clearly articulating the specific workready skills and attributes that are expected learning outcomes of WIL programs are important when placed within the context of increased employability being found to be the most important benefit of WIL programs by students.

The findings of this study have implications for the development of work-ready skills and embedding both WIL and non-WIL activities in undergraduate courses for business school educators and university policy makers. While the findings of this study should be generalised 
with some caution due to the small sample size, and while definitions for survey items were provided to both academics and students, due to the survey method adopted there is some potential for participants to have different understandings of the items under study. Notwithstanding these limitations, differences in views as to the importance of work-ready skills together with a clear misalignment between the students and academics as to the importance of specific work-ready skills suggest that there is much more work needed in the WIL space to satisfy stakeholder expectations and deliver the necessary work-ready skills being called for by employers.

Further research should be undertaken to consider industry partners’ perspectives. In doing so, additional insights would be provided to assist universities in managing any expectations gaps that may arise. Additionally, future research should also examine the views and perspectives of careers consultants who are often involved in organising and managing WIL industry placements. Whilst this study focused on all business students, irrespective of discipline of study, further research could be undertaken to examine how different discipline specific WIL programs are structured and address all stakeholders’ perspectives and needs. 


\section{Notes}

1. Industry stakeholders were initially included in the survey questionnaire distribution. Unfortunately, after several repeated mailings, only one response from industry was received. A random sample of organisations that were included in the sample frame were contacted and the main reasons given for no response were a lack of time and also a lack of interest. This lack of response reflects Couper (1997) who found that participants that are not interested in a research topic are more likely to refuse to participate. 
Table 1. Panel 1(a) and 1(b): Background Characteristics of Stakeholder Groups.

\section{Panel 1a: Student background characteristics}

Demographic characteristics

Total Sample $(n=50)$

\begin{tabular}{llrr}
\hline Age & Mean & 30.5 years & \\
& Minimum & 18 years & \\
Gender & Maximum & 58 years & $48 \%$ \\
& Female & 24 & $52 \%$ \\
Campus & Male & 26 & $2 \%$ \\
& Alice Springs & 1 & $62 \%$ \\
& Darwin & 31 & $18 \%$ \\
& External & 9 & $14 \%$ \\
& Melbourne & 7 & $4 \%$ \\
\hline
\end{tabular}

Panel 1b: Academic background characteristics

Demographic characteristics

\begin{tabular}{llrr}
\hline Age & Mean & 49.6 years & \\
& Minimum & 32 years & \\
\multirow{2}{*}{ Education sector } & Maximum & 66 years & $12.5 \%$ \\
& Vocational & 3 & $87.5 \%$ \\
& Education & 21 & $54.2 \%$ \\
\multirow{2}{*}{ Education level } & Higher Education & 13 & $45.8 \%$ \\
& Masters & 11 & $33.3 \%$ \\
& PhD & 8 & $4.2 \%$ \\
& Sessional & 1 & $62.5 \%$ \\
\hline
\end{tabular}


Table 2. Range of Questions in Relation to Work-ready skills

\begin{tabular}{lccc}
\hline Question & $\begin{array}{c}\text { Students } \\
(\boldsymbol{n}=\mathbf{5 0}) \\
\overline{\boldsymbol{x}}_{\mathbf{S}}\end{array}$ & $\begin{array}{c}\text { Academics } \\
(\boldsymbol{n}=\mathbf{2 4}) \\
\overline{\boldsymbol{x}}_{\mathbf{A}}\end{array}$ & $\begin{array}{c}\text { Mean } \\
\text { Difference } \\
\overline{\boldsymbol{x}}_{\mathbf{S}}-\overline{\boldsymbol{x}}_{\mathbf{A}}\end{array}$ \\
\hline $\begin{array}{l}\text { Networking with industry is important aspect of } \\
\text { student's learning }\end{array}$ & 4.96 & 5.21 & -0.25 \\
$\begin{array}{l}\text { Current work-ready skills are relevant to my } \\
\text { learning }\end{array}$ & 4.75 & 4.42 & 0.33 \\
$\begin{array}{l}\text { Work-ready skills are integrated effectively into } \\
\text { university's undergraduate degrees }\end{array}$ & 4.48 & 4.38 & 0.10 \\
$\begin{array}{l}\text { Work-ready skills are integrated effectively into } \\
\text { business undergraduate degrees }\end{array}$ & 4.42 & 4.25 & 0.17 \\
$\begin{array}{l}\text { Lecturers discuss work-ready skills and the } \\
\text { importance of them }\end{array}$ & 4.06 & $\mathrm{n} / \mathrm{a}$ & $\mathrm{n} / \mathrm{a}$ \\
$\begin{array}{l}\text { Students acquire work-ready skills regardless of } \\
\text { their discipline of study }\end{array}$ & 3.88 & 4.08 & -0.20 \\
$\begin{array}{l}\text { Work-ready skills are important to me } \\
\text { Respons }\end{array}$ & $3.23^{* * *}$ & $5.08^{* * *}$ & -1.85 \\
\hline
\end{tabular}

Responses were on a six-point scale from: 1 = strongly disagree; 2 = moderately disagree; $3=$ slightly disagree; 4 = slightly agree; 5 = moderately agree; and $6=$ strongly agree.

* Mann Whitney U Test of Independent Samples where $\mathrm{p}<0.05$ (two-tailed test); ${ }^{* *}$ Mann Whitney $U$ Test of Independent Samples where $p<0.01$ (two-tailed test); ${ }^{* * *}$ Mann Whitney $U$ Test of Independent Samples where $p<0.001$ (two-tailed test).

Table 3. WIL Activities Most Effective for Developing Student Work-ready skills.

\begin{tabular}{lcccc}
\hline Activities & \multicolumn{2}{c}{ Students $(\boldsymbol{n}=\mathbf{5 0})$} & \multicolumn{2}{c}{ Academics $(\boldsymbol{n}=\mathbf{2 4})$} \\
& $n$ & $\%$ & $n$ & $\%$ \\
\hline On-campus activities & 6 & 12.0 & 3 & 12.5 \\
Off-campus activities & 12 & 24.0 & 2 & 8.3 \\
Combination of on and off campus activities & 32 & 62.0 & 19 & 79.2 \\
\hline
\end{tabular}


Table 4. Importance of Work-ready skills

\begin{tabular}{lllll}
\hline Work-ready skills & \multicolumn{2}{l}{ Students $(\boldsymbol{n}=\mathbf{5 0})$} & \multicolumn{2}{l}{ Academics $(\boldsymbol{n}=\mathbf{2 4})$} \\
& $\bar{x}$ & Rank & $\bar{x}$ & Rank \\
\hline Project planning & $4.55^{* * *}$ & 1 & $3.85^{* * *}$ & 14 \\
Communication skills & 4.50 & 2 & 4.75 & 2 \\
Ability to work in a team & 4.48 & 3 & 4.35 & 5 \\
Employability skills & $4.46^{*}$ & 4 & $4.80^{*}$ & $=1$ \\
Discipline knowledge & 4.45 & 5 & 4.50 & $=3$ \\
Ability to use current technologies & 4.42 & 6 & 4.21 & 7 \\
Strategic thinking & 4.41 & $=7$ & 4.15 & 9 \\
Self-management & $4.41^{*}$ & $=7$ & $4.80^{*}$ & $=1$ \\
Decision making skills & 4.40 & 8 & 4.50 & $=3$ \\
Strategic management & $4.36^{* *}$ & $=9$ & $3.91^{* *}$ & 13 \\
Social responsibility & 4.36 & $=9$ & 4.15 & 9 \\
Flexibility & 4.33 & 10 & 4.42 & 4 \\
Innovation & 4.30 & 11 & 4.00 & 11 \\
Conflict management & 4.28 & $=12$ & 4.20 & 8 \\
Leadership skills & 4.28 & $=12$ & 4.10 & 10 \\
Creativity & 4.24 & 13 & 3.95 & 12 \\
Inter-generational tolerance & 4.23 & 14 & 4.25 & 6
\end{tabular}

Responses were on a five-point scale from: $1=$ unimportant; $2=$ of little importance; $3=$ moderately important; 4 = important; and 5 = very important.

* Mann Whitney U Test of Independent Samples where $\mathrm{p}<0.05$ (two-tailed test); ${ }^{* *}$ Mann Whitney $U$ Test of Independent Samples where $p<0.01$ (two-tailed test); ${ }^{* * *}$ Mann Whitney $U$ Test of Independent Samples where $p<0.001$ (two-tailed test).

Table 5. Range of Questions in Relation to WIL

\begin{tabular}{lccc}
\hline Question & $\begin{array}{c}\text { Students } \\
(\boldsymbol{n}=\mathbf{5 0 )} \\
\overline{\boldsymbol{x}}_{\mathbf{S}}\end{array}$ & $\begin{array}{c}\text { Academics } \\
(\boldsymbol{n}=\mathbf{2 4 )} \\
\overline{\boldsymbol{x}}_{\mathbf{A}}\end{array}$ & $\begin{array}{c}\text { Mean } \\
\text { Difference } \\
\overline{\boldsymbol{x}}_{\mathbf{S}}-\overline{\boldsymbol{x}}_{\mathbf{A}}\end{array}$ \\
\hline WIL offers students team skills development & 5.42 & 5.13 & 0.29 \\
WIL placements in relevant workplaces & 5.40 & 5.33 & 0.07 \\
Range of WIL benefit students & 5.34 & 4.92 & 0.42 \\
Difference knowledge of WIL vs non-WIL & 5.18 & 5.13 & 0.05 \\
Employability skills are main-focus of WIL & 5.14 & 4.75 & 0.39 \\
Strong link between WIL and employability & 5.00 & 4.96 & 0.04 \\
Workplace ethics should be taught prior to WIL & 4.96 & 5.42 & -0.46 \\
Focus on WIL should be driven from upper & 4.88 & 4.96 & -0.08 \\
management & 4.52 & 4.50 & 0.02 \\
NT has a unique workplace environment & 3.76 & 4.17 & -0.41 \\
University has a strong relationship with industry & 3.36 & 3.29 & 0.07 \\
WIL programs are better suited to VET courses &
\end{tabular}

Responses were on a six-point scale from: 1 = strongly disagree; 2 = moderately disagree; 3 = slightly disagree; 4 = slightly agree; 5 = moderately agree; and 6 = strongly agree. 
Table 6. Importance of WIL Expected Benefits.

\begin{tabular}{lllll}
\hline \multirow{2}{*}{ Expected Benefit } & \multicolumn{2}{l}{ Students $(\boldsymbol{n}=\mathbf{5 0})$} & \multicolumn{2}{c}{ Academics $(\boldsymbol{n}=\mathbf{2 4})$} \\
& $\bar{x}$ & Rank & $\bar{x}$ & Rank \\
\hline Increased employability & 4.42 & 1 & 4.21 & 5 \\
Communication skills & 4.36 & 2 & 4.46 & 2 \\
Professionalism & $4.34^{* *}$ & 3 & $4.50^{* *}$ & 1 \\
Employability skills & 4.28 & 4 & 4.26 & 4 \\
Discipline knowledge & 4.18 & 5 & 4.38 & 3 \\
Work-ready skills & 4.12 & 6 & 4.17 & 6 \\
\hline
\end{tabular}

Responses were on a five-point scale from: $1=$ not important; 2 = slightly important; $3=$ moderately important; 4 = very important; and 5 = extremely important.

** Mann Whitney $U$ Test of Independent Samples where $p<0.05$ (two-tailed test).

Table 7. Importance of Assistance to Manage a WIL Program

\begin{tabular}{lcr}
\hline Items & \multicolumn{2}{c}{ Academics $(\boldsymbol{n}=\mathbf{2 4})$} \\
& $\bar{x}$ & Rank \\
\hline Networking with employers & 4.57 & 1 \\
Specific guidelines & 4.14 & $=2$ \\
WIL teaching techniques & 4.14 & $=2$ \\
Best practice tools & 4.10 & $=3$ \\
Administrative assistance & 4.10 & $=3$ \\
Conflict management & 4.00 & 4 \\
Legal information & 3.90 & 5 \\
\hline
\end{tabular}

Responses were on a five-point scale from: 1 = not important; 2 = slightly important; 3 = moderately important; 4 = very important; and 5 = extremely important. 


\section{References}

Abbasi, F., A. Ali, and N. Bibi. 2018. "Analysis of Skill Gap for Business Graduates: Managerial Perspective from Banking Industry." Education+ Training 60 (4):354-67.

Abeysekera, I. 2006. "Issues Relating to Designing a Work-integrated Learning Program in an Undergraduate Accounting Degree Program and its Implications for the Curriculum." Asia-Pacific Journal of Cooperative Education 7 (1):7-15.

Abraham, S. E., and L. A. Karns. 2009. "Do Business Schools Value the Competencies that Businesses Value?" Journal of Education for Business 84 (6):350-6.

ACNielsen Research Services. 2000. Employer Satisfaction with Graduate Skills: Australia. Department of Education, Training and Youth Affairs. ISBN: 0642239738

Andrews, J., and H. Higson. 2008. "Graduate Employability, 'Soft Skills’ Versus 'Hard’Business Knowledge: A European Study." Higher Education in Europe 33 (4):411-22.

Archer, W., and J. Davison. 2008. "Graduate Employability." In The council for industry and Higher Education. Accessed 18 June 2017: https://www.brunel.ac.uk/_data/assets/pdf_file/0009/92718/CIHE__0802Grademployability1.pdf

Atrostic, B. N. Bates, and A. Silberstein. 2001. "Nonresponse in US Government Household Surveys: Consistent Measures, Recent Trends, and New Insights." Journal of Official Statistics 17, no. 2: 209.

Australian Business Deans Council (ABDC). 2008. "Business as Usual: A Collaborative and Inclusive Investigation of Existing Resources, Strengths, Gaps and Challenges to be Addressed for Sustainability in Teaching and Learning in Australian University Business Faculties." In.: Carrick Institute for Teaching and Learning in Higher Education. Accessed 31 ${ }^{\text {st }}$ July 2013: http://www.olt.gov.au/resource-business-asusual-sustainability-sydney-2008

Australian Learning and Teaching Council. 2009. "Communique." In, edited by Australian Government Department of Education Employment \& Workplace Relations, 1-60. Accessed 31 ${ }^{\text {st }}$ August 2017: http://www.olt.gov.au/altc-communique?year=2009

Barrie, S. 1999. "Assessment: Defining the Worth of Professional Practice." In Australian Association for Research in Education Annual Conference. Melbourne: Institute for Teaching and Learning. Accessed $3^{\text {rd }}$ June 2018: http://www.aare.edu.au/data/publications/1999/bar99509.pdf

Barrie, S. 2006. "Understanding What We Mean by Generic Attributes of Graduate." Higher Education 51 (2):215-41.

Barrie, S, C Hughes, and C Smith. 2009. "The National Graduate Attributes Project: Integration and Assessment of Graduate Attributes in Curriculum." In.: University of Sydney, University of Queensland,Griffith University.

Biggs, J, and C Tang. 2011. Teaching for Quality Learning at University. 4th ed: McGrawHill Education (UK).

Brick, J. and D. Williams. 2013. "Explaining Rising Nonresponse Rates in Cross-sectional Surveys. The ANNALS of the American Academy of Political and Social Science, 645(1), 36-59.

Brimble, M., and B. Freudenberg. 2010. "Will WIL'ing Work?" In B-HERT Newsletter, 2-4. Accessed $18^{\text {th }}$ February 2019: https://papers.ssrn.com/sol3/papers.cfm?abstract_id=1568545

Chavan, M., and L. Carter. 2018. "Management Students-Expectations and Perceptions on Work Readiness." International Journal of Educational Management 32 (5):825-50. 
Clark, L., A. Rowe, A. Cantori, A. Bilgin, and V. Mukuria. 2016. "The Power Dynamics and Politics of Survey Design: Measuring Workload Associated with Teaching, Administering and Supporting Work-integrated Learning Courses." Studies in Higher Education 41 (6):1055-73.

Collin, K., and P. Tynjala. 2003. "Intergrating Theory and Practice? Employees' and Students' Experiences of Learning at Work." Journal of Workplace Learning 15 (7/8):338-44.

Cooper, L, J Orrell, and M Bowden. 2010. Work Integrated Learning; A Guide to Effective Practice. New York, NY: Routledge.

Couper, M. 1997. "Survey Introductions and Data Quality." Public opinion quarterly 61 (2):317-38. doi: doi:10.1086/297797.

Cumming, J. 2010. "Contextualised Performance: Reframing the Skills Debate in Research Education." Studies in Higher Education 35 (4):405-19.

Dressler, S., and A. Keeling. 2011. "Benefits of Cooperative and Work-integrated Education for students." In International Handbook for Cooperative and Work-integrated Education: International Perspectives of Theory, Research and Practice, edited by R. Coll and K. Zegwaard, 261-75. Lowell, Massachusetts: World Association for Cooperative Education.

Ernst \& Young. "Higher Education and the Power of Choice." Accessed $12^{\text {th }}$ March 2017: http://www.ey.com/Publication/vwLUAssets/Higher_education_and_the_power_of_c hoice_Australia/\$File/Higher\%20education\%20and\%20the\%20power\%20of\%20choi ce\%20Australia.pdf.

Freudenberg, B., M. Brimble, and C. Cameron. 2011. "WIL and Generic Skill Development: The Development of Business Students' Generic Skills through Work-integrated Learning." Asia Pacific Journal of Cooperative Education 12 (2):79-93.

Gill, R. 2018. "Building Employability Skills for Higher Education Students: An Australian Example." Journal of Teaching and Learning for Graduate Employability 9 (1):8492.

Gold, J., R. Holden, P. Iles, J. Stewart, and J. Beardwell. 2013. Human Resource Development: Theory and Practice: Macmillan International Higher Education.

Gribble, C. 2014. "Employment, Work Placements \& Work Integrated Learning of International Students in Australia." International Education Association of Australia, Research Digest 2.

Groves, R. 2011. “Three Eras of Survey Research,” Public Opinion Quarterly, 75(5), pp. $861-871$.

Hair, J., W. Black, B. Babin, and R. Anderson. 2010. Multivariate Data Analysis: International Version. Upper Saddle River New Jersey: Pearson Prentice Hall.

Harrison, G, and K Felton. 2013. "Fair Go in the Field: Inclusive Field Education for International Students in the Social Sciences: Final Report." In.: Sydney, NSW, Australia: Office for Learning and Teaching. Retrieved from the Office for Learning and Teaching website: http://www.olt.gov.au/project-fair-go-fieldinclusive-fieldeducation-international-students-social-sciences-2012.

Jackson, D. 2009. "Undergraduate Management Education: Its Place, Purpose and Efforts to Bridge the Skills Gap." Journal of Management and Organization 15 (2):206-23.

Jackson, D. 2012. "Testing a Model of Undergraduate Competence in Employability Skills and its Implications for Stakeholders." Journal of Education and Work:1-23.

Jackson, D. 2013a. "Business Graduate Employability- Where Are We Going Wrong?" Higher Education Research and Development 32 (5):776-90.

Jackson, D. 2013b. "Student Perceptions of the Importance of Employability Skills Provision in Business Undergraduate Programs." Journal of Education for Business 88 (5):2719. 
Jackson, D. 2016. "Deepening Industry Engagement with International Students through Work-integrated Learning." Australian Bulletin of Labour 42 (1):38.

Jackson, D., and E. Chapman. 2012. "Non-technical Skills Gaps in Australian Business Graduates." Education + Training 54 (2):95-113.

Jensen, K. 2009. "Why Work Experience Matters! Real Prospects 2009 Graduates’ Experiences of Placements, Internships and Work Experience." Higher Education Careers Services Unit, Manchester.

Jorre de St Jorre, T., and B. Oliver. 2017. "Want Students to Engage? Contextualise Graduate Learning Outcomes and Assess for Employability." Higher Education Research \& Development:1-14.

Kavanagh, M., and L. Drennan. 2008. "What Skills and Attributes Does an Accounting Graduate Need? Evidence from Student Perceptions and Employer Expectations." Accounting \& Finance 48 (2):279-300.

Kreber, C. 2006. "Setting the Context: The Climate of University Teaching and Learning." New Directions for Higher Education 133:5-11.

Lawson, R., E. Fallshaw, T. Papadopoulos, T. Taylor, and M. Zanko. 2011. "Professional Learning in the Business Curriculum: Engaging Industry, Academics and Students." Asian Social Science 7 (4):61-8.

Lowden, K., S. Hall, D. Elliot, and J. Lewin. 2011. "Employers' Perceptions of the Employability Skills of New Graduates." London: Edge Foundation.

McIlveen, P., S. Brooks, A. Lichtenberg, A. Smith, P. Torjul, and J. Tyler. 2008. "Career Development Learning \& Work-integrated Learning in Australian Higher Education: A Discussion Paper." In National Symposium on Career Development Learning: Maximising the Contribution of Work-integrated Learning (WIL) to the Student Experience, 83. Melbourne, Australia: National Association of Graduate Careers Advisory Services Australia, Inc.

Mckinnon, S. 2011. "Closing the Gap: The Benefits and Challenges of Embedding Workrelated Learning in the Taught Curriculum." In 8th QAA Enhancement Themes Conference. Heriot Watt University, Edinburgh.

McLennan, B., and S. Keating. 2008. "Work-integrated Learning (WIL) in Australian Universities: The Challenges of Mainstreaming WIL." In ALTC NAGCAS National Synopsium June 2008. Melbourne.

McMurray, S., M. Dutton, R. McQuaid, and A. Richard. 2016. "Employer Demands From Business Graduates”. Education+ Training, 58(1), 112-132.

Moreau, MP., and C. Leathwood. 2006. "Graduates' Employment and the Discourse of Employability: A Critical Analysis." Journal of Education and Work 19 (4):305-24.

Oliver, B. 2010. "Teaching Fellowship: Benchmarking Partnerships for Graduate Employability." In Final Report, edited by Australian Learning \& Teaching Council.

Oliver, B. 2011. "Assuring Graduate Capabilities: Good Practice Report." Sydney: Australian Learning and Teaching Council.

Oliver, B., S. Jones, S. Ferns, and B. Tucker. 2007. Mapping Curricula: Ensuring Work-ready Graduates by Mapping Course Learning Outcomes and Higher Order Thinking Skills. Paper presented at the A Conference for University Teachers.

Orrell, J. 2011. "Good Practice Report: Work-integrated Learning." In.

Patrick, C-J., D. Peach, C. Pocknee, F. Webb, M. Fletcher, and G. Pretto. 2008. "The WIL (Work Integrated Learning) Report: A National Scoping Study." In. Brisbane, Australia: Queensland University of Technology.

PwC (PricewaterhouseCoopers Australia). 2016. "Australian Higher Education Workforce of the Future: Report." In, edited by Australian Higher Education Industrial Association. QS. 2018. "The Global Skills Gap in the 21st Century." In, edited by Quacquarelli Symonds. 
Rae, D. 2007. "Connecting Enterprise and Graduate Employability; Challenges to the Higher Education Culture and Curriculum?" Education \& Training 49 (8/9):605-19.

Rhodes, G., and G. Shiel. 2007. "Meeting the Needs of the Workplace and the Learner Through Work-based Learning." Journal of Workplace Learning 19 (3):173-87.

Rindfuss, R. R., M. Chloe, O. Tsuya, , L. Bumpass, and E. Tamaki, (2015). "Do Low Survey Response Rates Bias Results? Evidence from Japan”. Demographic Research, 32, 797-828.

Rook, L. 2015. "Work-integrated Learning Programs in Human Resource Management." University of Western Sydney.

Rowe, A, T Winchesster-Seeto, and J Mackaway. 2012. “That’s not really WIL! - building a typology of WIL and related activities.” Proceedings of the Australian Collaborative Network (ACEN), National Conference Deakin University, Geelong: 246-251.

Rowe, A., and K. Zegwaard. 2017. "Developing Graduate Employability Skills and Attributes: Curriculum Enhancement through Work-integrated Learning." Asia Pacific Journal of Cooperative Education 18 (2):87-99.

Silva, P., B. Lopes, M. Costa, D. Seabra, A. Melo, E. Brito, and G. Dias. 2016. "Stairway to Employment? Internships in Higher Education." Higher Education 72 (6):703-21.

Singer, E. (2006), “Nonresponse Bias in Household Surveys,” Public Opinion Quarterly, 70 (5):637-645.

Sleap, M., and H. Reed. 2006. "Views of Sport Science Graduates Regarding Work Skills Developed at University." Teaching in Higher Education 11 (1):47-61.

Smith, M., S. Brooks, A. Lichtenberg, P. McIlveen, P. Torjul, and J. Tyler. 2009. "Career Development Learning: Maximising the Contribution of Work-integrated Learning to the Student Experience." In.: Australian Learning and Teaching Council and the National Association of Graduate Careers Advisory Services.

Tomlinson, M. 2008. "'The Degree is Not Enough': Students’ Perceptions of the Role of Higher Education Credentials for Graduate Work and Employability." British journal of sociology of education 29 (1):49-61.

Tynjala, P., J. Valimaa, and A. Sarja. 2003. "Pedagogical Perspectives on the Relationships Between Higher Education and Working Life." Higher Education 46 (2):147-66.

Universities Australia, and Australian Collaborative Education Network. 2015. "National Strategy on Work Integrated Learning in University Education." In.

Venkatraman, S., F. Wahr, A. de Souza-Daw, and S. Kaspi. 2016. "Integrating Generic Skills into Disciplinary Curricula." World Academy of Science, Engineering and Technology, International Journal of Social, Behavioral, Educational, Economic, Business and Industrial Engineering 11 (1):102-6.

Weisz, M. 2000. "Developing a Measure of Student Attributes." Journal of Cooperative Education 35 (2/3):33-40. 


\section{Appendix A}

\begin{tabular}{|c|c|}
\hline \multicolumn{2}{|c|}{ Table 2} \\
\hline Survey question & Literature \\
\hline $\begin{array}{l}\text { Networking with industry is important aspect of } \\
\text { student's learning }\end{array}$ & Rook (2015) re networking \\
\hline $\begin{array}{l}\text { Current work-ready skills are relevant to my } \\
\text { learning }\end{array}$ & Specific to the university \\
\hline $\begin{array}{l}\text { Work-ready skills are integrated effectively into } \\
\text { university’s undergraduate degrees }\end{array}$ & Specific to the university \\
\hline $\begin{array}{l}\text { Work-ready skills are integrated effectively into } \\
\text { business undergraduate degrees }\end{array}$ & Jackson (2009) recommendation on page 10 \\
\hline $\begin{array}{l}\text { Lecturers discuss work-ready skills and the } \\
\text { importance of them }\end{array}$ & Jackson (2009) recommendation on page 10 \\
\hline $\begin{array}{l}\text { Students acquire work-ready skills regardless of } \\
\text { their discipline of study }\end{array}$ & $\begin{array}{l}\text { Literature dating back to the } 1980 \text { consistently } \\
\text { reveals dissatisfaction with business graduates of } \\
\text { their soft skills or work-ready skills (Jackson } \\
\text { 2009). The application of WIL models vary from } \\
\text { discipline to discipline and participants in Rooks } \\
\text { study suggested that as a result work ready skills } \\
\text { may become too discipline specific (Rook 2015) }\end{array}$ \\
\hline Work-ready skills are important to me & Authors \\
\hline
\end{tabular}

\begin{tabular}{|l|l|}
\hline \multicolumn{2}{|c|}{ Table 3 } \\
\hline Survey question & Literature \\
\hline $\begin{array}{l}\text { Structure of WIL activities most effective for } \\
\text { developing work ready skills }\end{array}$ & Rowe, Winchester-Seeto and Mackaway (2012) \\
\hline
\end{tabular}

\begin{tabular}{|l|l|}
\hline \multicolumn{2}{|c|}{ Table 4} \\
\hline Skill & Literature \\
\hline Project planning & $\begin{array}{l}\text { Jackson and Chapman (2012) findings re project } \\
\text { planning }\end{array}$ \\
\hline Communication skills & Specific to the university \\
\hline Ability to work in a team & Specific to the university \\
\hline Employability skills & $\begin{array}{l}\text { Rowe,Winchester-Seeto and Mackaway (2012) } \\
\text { findings re employability skills }\end{array}$ \\
\hline Discipline knowledge & $\begin{array}{l}\text { Cooper, Orrell and Bowden (2010) conclusion re } \\
\text { discipline knowledge }\end{array}$ \\
\hline Ability to use current technologies & Specific to the university \\
\hline Strategic thinking & Authors \\
\hline Self-management & Specific to the university \\
\hline Decision making skills & Jackson and Chapman (2012) findings re decision \\
making skills
\end{tabular}




\begin{tabular}{|l|l|}
\hline Conflict management & $\begin{array}{l}\text { Jackson and Chapman (2012) findings re conflict } \\
\text { management }\end{array}$ \\
\hline Leadership skills & $\begin{array}{l}\text { Jackson and Chapman (2012) findings re leadership } \\
\text { skills }\end{array}$ \\
\hline Creativity & Specific to the university \\
\hline Inter-generational tolerance & Specific to the university \\
\hline \multicolumn{2}{|c|}{ Table 5 } \\
\hline Survey question & Literature \\
\hline WIL offers students team skills development & Authors \\
\hline WIL placements in relevant workplaces & Rook (2015) \\
\hline Range of WIL benefit students & Zegward and Coll (2011) findings \\
\hline Difference knowledge of WIL vs non-WIL & $\begin{array}{l}\text { Edwards, Perkins, Pearce and Hong (2015); } \\
\text { Hodges (2011); Smith, Ferns, } \\
\text { Russell and Cretchley (2014) }\end{array}$ \\
\hline Employability skills are the main-focus of WIL & Authors \\
\hline Strong link between WIL and employability & Smith, Brooks, Lichtenberg, McIlveen, Torjul and \\
& Tyler (2009) findings page 13 \\
\hline Workplace ethics should be taught prior to WIL & Authors \\
\hline Focus on WIL should be driven from upper & $\begin{array}{l}\text { Cooper, Orrell and Bowden (2010) page 31 } \\
\text { mand Orrell (2011) conclusions }\end{array}$ \\
\hline NT has a unique workplace environment & Authors \\
\hline University has a strong relationship with industry & $\begin{array}{l}\text { Patrick, Peach, Packnee, Webb, Fletcher } \\
\text { and Pretto (2008) findings re importance of } \\
\text { industry }\end{array}$ \\
\hline \multirow{2}{*}{$\begin{array}{l}\text { WIL programs are better suited to VET courses } \\
\text { Rooks (2015) findings }\end{array}$} \\
\hline
\end{tabular}

\begin{tabular}{|c|c|}
\hline \multicolumn{2}{|c|}{ Table 6} \\
\hline Survey question & Literature \\
\hline WIL offers students team skills development & $\begin{array}{l}\text { Patrick, Peach, Packnee, Webb, Fletcher } \\
\text { and Pretto (2008) }\end{array}$ \\
\hline Communication skills & $\begin{array}{l}\text { Abraham and Karns (2009); Archer and } \\
\text { Davidson (2008); Cumming (2010); } \\
\text { Jackson (2013b); QS (2018) }\end{array}$ \\
\hline Professionalism & $\begin{array}{l}\text { Barrie (1999); Lawson, Fallshaw, Papadopoulos, } \\
\text { Taylor and Zanko (2011) }\end{array}$ \\
\hline Employability skills & McLennan and Keating (2008) \\
\hline Discipline knowledge & Authors \\
\hline Work-ready skills & $\begin{array}{l}\text { Patrick, Peach, Packnee, Webb, Fletcher } \\
\text { and Pretto (2008); Mclennan and Keating (2008) }\end{array}$ \\
\hline
\end{tabular}

\begin{tabular}{|l|l|}
\hline \multicolumn{2}{|c|}{ Table 7 } \\
\hline Survey question & Literature \\
\hline Networking with employers & Rook (2015) \\
\hline Specific guidelines & Rook (2015) \\
\hline WIL teaching techniques & Rook (2015) \\
\hline Best practice tools & Rook (2015) \\
\hline Administrative assistance & Rook (2015) \\
\hline Conflict management & Rook (2015) \\
\hline Legal information & Rook (2015) \\
\hline
\end{tabular}


